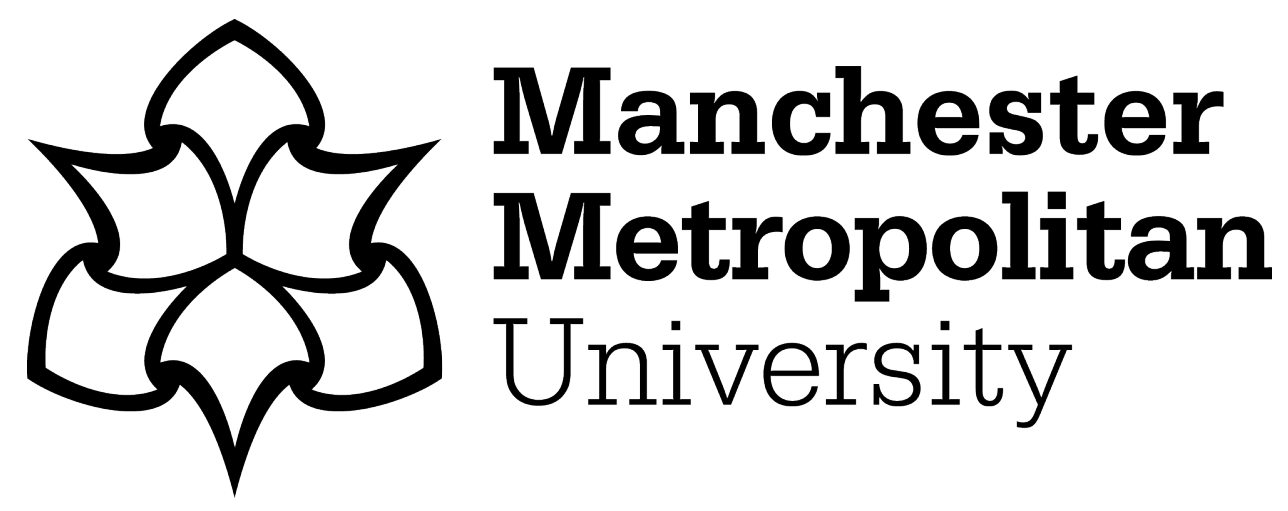

Edwards, SR (2018) An Empire of Memory: Overseas British War Cemeteries, 1917-1983. International Journal of Military History and Historiography, 38 (2). pp. 255-286. ISSN 2468-3302

Downloaded from: https://e-space.mmu.ac.uk/621086/

Version: Accepted Version

Publisher: Brill

DOI: https://doi.org/10.1163/24683302-03802006

Please cite the published version 


\section{An Empire of Memory: Overseas British War Cemeteries, 1918-1983}

\section{Sam Edwards, Manchester Metropolitan University}

The extent to which the First World War ruptured history and, in doing so, catalysed the production of new artistic and aesthetic forms has been much discussed and debated by literary scholars and art historians. Such discussions have similarly informed understandings of the war's commemorative response, with Paul Fussell famously contending that the deluge of 1914-18 called forth the age of 'modern memory', whilst Jay Winter has argued that for all it's 'newness' the memorials which followed the war's end in fact reconstructed and re-established traditional conceptions of mourning and monumentality. ${ }^{1}$ Following Winter, this article explores the ways in which an Edwardian ideal focused on a carefully cultivated 'English Garden' style emerged in the British Empire after 1918 as the dominant aesthetic of commemorative contemplation, albeit it with subtle accommodations often made for national difference and cultural distinction. This implicitly nostalgic aesthetic - with roots in early twentieth century ruralism - duly shaped the commemorative response to the second global conflict of the twentieth century, with new cemeteries shaped by 'old' ideas established across the globe, from Bayeux, to Baghdad, to Bombay. Combined, these carefully cultivated memorial landscapes re-energised a set of Edwardian certainties that in many respects, and the IWGC's activities notwithstanding, had already foundered by 1918, crushed under the weight of the twentieth century and all its horrors. By the 1940s, indeed, the challenges were still more profound, with the Empire dissolving at the very same moment that the 'Imperial' War Graves Commission built new commemorative outposts. Seen in this context, these cemeteries were the final territorial acquisitions of an Empire in decline, their apparent permanence belying the immense political, military and economic transitions amidst which they were commenced and completed.

Ironically, it took a final and belated demonstration of Imperial power to make this apparent. For in 1982, the now renamed Commonwealth War Graves Commission organised the construction of a new cemetery on the Falkland Islands, recently the scene of a conflict with Argentina over the question of sovereignty. This was the first new military cemetery involving the CWGC established since the Second World War, and in the details of its design it stands as a marker for how far the Edwardian ideals of 1918 had increasingly lost traction in late twentieth century Britain even as it nonetheless had one final flourish. Conceived as gardens of England and built as enclaves of Empire, Britain's war cemeteries are thus expressive of the expansion and contraction of the twentieth century Imperial and post-Imperial State. Indeed, in a sense, these landscapes chart the post-1945 transition from a formal Empire of rule and occupation to an informal Empire - or Commonwealth - of sentiment, culture and memory. ${ }^{2}$ Today, however, as even the ties of this Commonwealth begin to fade, the IWGC's cemeteries risk a future akin to the Roman Forts of the Saxon Shore. They are the last architectural remnants of an Imperial power whose day is done, and whose soldiers can no longer be spared to man the Frontier, in life or in death.

\footnotetext{
${ }^{1}$ P. Fussell, The Great War and Modern Memory (Oxford: Oxford University Press, 2000); J. Winter, Sites of Memory, Sites of Mourning: The Great War in European cultural history (Cambridge: Cambridge University Press, 1995).

${ }^{2}$ For the idea of 'informal empire', see J. Gallagher and R. Robinson, 'The Imperialism of Free Trade', Economic History Review, Vol. 6, No. 1, (1953), pp. 1-15.
} 


\section{Gardens of England: The IWGC in Europe, 1917-1939}

The establishment during the First World War of the Imperial War Graves Commission (IWGC), the organisation tasked with supervising the collection, burial and commemoration of the Empire's war dead, was without any real precedent in British history. To be sure, among the regular soldiery, Victoria's wars of Empire had long produced their fair share of maimed, missing and killed. But across much of the nineteenth century neither the political nor the military authorities seem to have felt any real compunction to duly inter, repatriate or memorialise those fallen for the flag. Even by the early twentieth century not that much had changed: after 'playing the game' in the heat of the South African veldt, the fallen Regular was often left as carrion for the crows, a fact movingly acknowledged by Thomas Hardy in his poem 'Drummer Hodge':

They throw in Drummer Hodge, to rest

Uncoffined -- just as found:

His landmark is a kopje-crest

That breaks the veldt around:

And foreign constellations west

Each night above his mound. ${ }^{3}$

Discussing this history of long-running official disinterest, the historian of the British soldier, Richard Holmes, has thus noted that for much of Victoria's reign those who fell on the field of battle were 'usually tumbled half-naked into mass graves whose sites are rarely marked, and there was little dignity to the business' ${ }^{4}$

Policy during and after the First World War was different. For those such as Sir Fabian Ware, who in 1914 drove efforts to order and organise the collection of war dead, the sheer scale of destruction during the First World War, especially along the Western Front, demanded a more considered plan. Initially, Ware helped to found the British Red Cross Society Mobile Unit, which was duly re-designated the Graves Registration Commission in 1915, becoming the IWGC in 1917. As Phillip Longworth and David Crane have explained, the challenge before the newly formed IWGC was monumental, in all senses of the word: British Empire deaths were near one million, at least 200,000 of which were from the colonies and dominions. ${ }^{5}$ At root, new and evermore destructive military technologies were responsible for the changed nature of combat and, in particular, the vastly increased death toll. Machine guns, mines, massive artillery and, by 1917 aircraft and armour, all exacted a heavy price on those ordered to climb the parapet of their trenches and march towards the enemy (often in a manner which their Victorian predecessors would have recognised). In short, twentieth century 'total war' harvested lives in their thousands and, perhaps most horrifying of all, disappeared bodies. As a result, and citing practicalities, logistics, and a commitment to democratic egalitarianism, the Imperial War Cabinet resolved in 1916 that all those who fell for King and Empire would be

\footnotetext{
${ }^{3}$ T. Hardy, 'Drummer Hodge' (1899): http://www.bbc.co.uk/poetryseason/poems/drummer hodge.shtml Accessed: 26 January 2018.

${ }^{4}$ R. Holmes, Redcoat: The British Soldier in the Age of Horse and Musket, p. 419.

${ }^{5}$ For an official history of the IWGC (later renamed the CWGC), see P. Longworth, The Unending Vigil: A History of the Commonwealth War Graves Commission, 1916-1967 (London: Constable, 1967). See also T.A. Gibson and K. Ward, Courage Remembered (London: Her Majesty's Stationary Office, 1989); D. Crane, Empires of the Dead, (London: William Collins, 2014); M. Heffermen, 'For Ever England: the Western Front and the Politics of Remembrance in Britain', Ecumeme, Vol. 2, No. 3, (1995), pp. 293-323.
} 
laid to rest - where this was possible - in the very fields of battle. ${ }^{6}$ For some families, this was an appropriation too far: the State had taken their son, and now, refusing to return him, demanded he perform military service for all time to come. For others, this was duty rightly and gratefully - repaid: those who served and sacrificed were to be guaranteed that Victorian obsession, a 'decent burial', and, as Kipling decreed, their name would thus 'liveth for evermore'?

Fabian Ware's IWGC was therefore founded as a practical response to the sheer scale of death and in response to this profound reckoning with the fragility and impermanence of the body. For millennia, the body - its veneration, internment, disposal, resurrection - had been central to the social processes and practices of ritual, memory and mourning. And then came war; bloody, brutal, industrial, atomising war. As a result, and at both home and abroad, there developed a new commemorative grammar, and a new commemorative architecture. In cities, towns and villages throughout the Empire the absent dead were brought home via carefully placed structures that recorded their lives and loss in various ways. Some were eternalized as ever-vigilant sentinels; some as warrior youth headed for battle; and some as sainted soldiers whose sacrifice had redeemed the sins of the living. ${ }^{8}$ Regardless of the specifics of form and style, many of these designs implicitly sought to restore - visually - the body of those obliterated or disappeared. Bodies broken by industrialized combat were resurrected in stone and statuary. Even where such corporeal resurrection was not quite so explicit, it remained implied or assumed. See, for example, the other popularly employed symbolism of post-1918 memorials: the Cross. See too, the central place of names in post-war commemorative culture: these were signifiers with intensified meaning precisely because the signified - the body - was no more. In a bodiless death culture, names were both substitute and substance. ${ }^{9}$

On the Western Front, meanwhile, where hundreds of thousands of bodies remained, the IWGC organised itself to design and deliver the commemorative counterpart to those structures established in communities across the Empire. ${ }^{10}$ Similar to that employed by those back home in Blighty, the commemorative grammar the Commission invoked drew upon precedent and made full use of the panoply of turn of the twentieth century mores and ideals. Thus, just as many British and Dominion towns and villages often opted for various shades of Edwardian Classicism, a choice most famously affirmed by the dedication in 1920 of Edwin Lutyens' Cenotaph, so too did the IWGC (with Lutyens again closely involved) explore the potential to impart meaning via Classical forms and style. In terms of the burial grounds the IWGC eventually established - and there were 900 alone along the Western Front - this resulted in the inclusion in the larger cemeteries of a non-denominational 'Stone of

\footnotetext{
${ }^{6}$ Longworth, Unending Vigil, pp. 41-42, 46-47.

${ }^{7}$ For some details of the post-war debate regarding where to bury the dead, see Longworth, Unending Vigil, pp. 46-47. See also D. Crane, Empires of the Dead, pp. 138-165.

${ }^{8}$ For details of the massive programme of public architecture which followed the war, see A. King, Memorials of the Great War in Britain: The Symbolism and Politics of Remembrance (Oxford: Berg, 1998). See also: J. Bartlett and K.M. Ellis, 'Remembering the Dead in Northrop: First World War Memorials in a Welsh Parish', Journal of Contemporary History, Vol. 34, No. 2 (1999), pp. 231-242; K.S. Inglis, 'The Homecoming: The War Memorial Movement in Cambridge, England', Journal of Contemporary History, Vol. 27, No. 4, (Oct. 1992), pp. 583-605.

${ }^{9}$ For the significance of names in post-1918 commemorative culture, see T. Laqueur, 'Memory and Naming in the Great War', in J.R. Gillis (ed.) Commemorations: The Politics of National Identity, (Princeton: Princeton University Press, 1993), pp. 150-167; B. Bushaway, 'Name upon Name; the Great War and Remembrance', in R. Porter (ed.) Myths of the English, (Cambridge: Polity Press, 1992), pp. 136-167.

${ }^{10}$ For details of the initial plans and ideas, see F. Kenyon, War Graves: How the Cemeteries Abroad will be Designed (London: His Majesty's Stationary Office, 1918).
} 
Remembrance': an alter like structure upon which was carved Kipling's legend, taken from Ecclesiasticus. Elsewhere, and again in a manner suggestive of the close connections between domestic and overseas commemorative endeavours, the other style popular with contemporary architects and sculptors centred around the medievalism of the still lingering Gothic Revival. ${ }^{11}$ Indeed, tellingly, this too was apparent on the very same day that the Cenotaph was dedicated. For a key part of the unveiling ceremony in Whitehall involved a funereal march past of soldiers, statesmen, and King, all before a gun-carriage bearing an Unknown Warrior later to be interred at that national shrine to medieval England, Westminster Abbey. ${ }^{12}$ Within the cemeteries of the IWGC, meanwhile, it was Lutyens great rival, Reginald Blomfield, who most obviously asserted this commitment to the commemorative potential of a very English medievalism. Thus, the visitor will often find an imposing and Blomfield designed 'Cross of Sacrifice' - with inspiration provided by a Crusader's sword - placed close to a Classically inspired and Lutyens' designed Stone of Remembrance. ${ }^{13}$ For some in the British Establishment, and especially in the Church of England, this was a necessary nod towards Christian iconography given the Commission's apparent disinterest in using overt religious symbolism. $^{14}$

If the architecture of the IWGC cemeteries recorded - and frequently fused contemporary commitment to certain historically resonant design aesthetics, the Commission's choice of horticulture and landscaping found inspiration in the concept of the English Garden. This was a landscape ideal mobilized as an essential ingredient 'in the iconography of British war cemeteries which were, literally, meant to represent an unambiguous corner of a foreign field/That is for ever England'. ${ }^{15}$ To this end, the early - and often temporary - cemeteries were sown with various wild flowers and grasses purposefully designed to soften landscapes which, in the words of Samuel Hynes, had been rendered barren, lifeless, 'dead'. ${ }^{16}$ Later, as the newly formed IWGC began planning the permanent cemeteries, such ideas were continued and further refined, although, perhaps predictably, planting now became more regulated and indeed regimented, with the organic and unruly qualities of the temporary cemeteries replaced by order, organisation and linear headstones of Portland stone. Even so, and in line with a very Victorian ideal of the landscaped cemetery garden, flowers remained central to the design aesthetic, with the English Rose emerging as an oft-used mechanism through which to visually - anglicize landscapes within which the soldier dead were similarly 'planted' ${ }^{17}$ As Morris has identified, the result was a complex gendering of the war cemetery as commemorative and political space. On the one hand, the liberal use of flowers suggested the English cottage garden, a space conventionally feminine in form, function and upkeep, whilst depictions of a feminized pastoral landscape - which the cemeteries were designed to imply -

\footnotetext{
${ }^{11}$ For a details discussion of invocation of 'medieval memory' in post-1918 Britain and Germany, see S. Goebbel, The Great War and Medieval Memory: War, Remembrance and Medievalism in Britain and Germany, 1914-1940 (Cambridge: Cambridge University Press, 2007).

${ }^{12}$ For an extended discussion of the Unknown Warrior, see N. Hansen, The Unknown Soldier: The Story of the Missing of the Great War (London: Corgi, 2007).

${ }^{13}$ For a detailed discussion of the role played by Sir Edwin Lutyens in the post-war cemetery building programme, see T. Skelton and G. Gliddon, Lutyens and the Great War (London: Frances Lincoln, 2008).

${ }^{14}$ See A. Wilkinson, The Church of England and the First World War (London: S.P.C.K, 1978). See also Crane, Empires of the Dead, pp. 148-150.

${ }^{15}$ M. Morris, "Gardens "For Ever England": Landscape, Identity and the First World War Cemeteries on the Western Front', Ecumene, Vol. 4, No. 4 (1997), p. 411.

${ }^{16}$ S. Hynes, A War Imagined: The First World War and English Culture (The Bodley Head, London, 1990).

${ }^{17}$ For the importance of the 'Rose' within Edwardian culture, see Fussell, Great War and Modern Memory, pp. 243-254.
} 
had been deployed during the war as the 'home' for which the male soldier must fight. ${ }^{18}$ On the other hand, such flowers germinated in soil fertilized by the very bodies of the soldier dead, whilst 'gardening' as an occupation fell firmly within the male 'sphere'. Such masculine associations were further complicated by a post-1918 'back to the land' movement which called for national and Imperial regeneration through a return to 'yeoman' agriculture. For the likes of Adrian Bell, Henry Williamson, J. Wentworth Day and H.J. Massingham, a rugged and masculine English identity was literally to be rediscovered among the fields and furrows of rural England, and in this sense the soldier dead had, as ever, led the way. ${ }^{19}$ For they had indeed 'returned' to the land, their deceased and decaying bodies retaining sufficient potency to regenerate a foreign place into an English and Imperial space. As Morris has remarked, 'Men's bodies, emasculated like Attis and planted like seed within a national monument, could represent hope through sacrifice and contact with the soil and nature' ${ }^{20}$

The Commission's largest cemetery on the Western Front (and indeed in the world), established at Tyne Cot near the Belgian market town of Ypres is indicative of how some of the architects involved brought together these various themes, ideas and aesthetics. The cemetery was designed by Sir Herbert Baker, an architect previously involved in the construction of government buildings in India and South Africa (and thus a man familiar with the demands of architectural anglicisation in the interests of Empire). Baker took as his inspiration the conventions of English ecclesiastical and collegial architecture, at one point explaining that he wished the completed cemetery to have 'the appearance of a huge, wellordered English churchyard with its yews and cedars behind the great flint wall, reminiscent of the walls of the precincts of Winchester [College]'. ${ }^{21}$ Thus, the surrounding wall and entranceway features Romanesque arches and turrets, whilst the Cross of Sacrifice - known as the 'Great Cross' - was carefully placed, at the suggestion of King George V, on ground formerly occupied by a German blockhouse (a powerful statement of conquest and possession). And just like the English churchyard Baker envisaged, poplar and yew trees break up the otherwise clean lines of headstones and boundary wall, all in Portland stone.

By the end of the 1930s, therefore, cemeteries like those at Tyne Cot provided a reassuringly solid intervention into an issue just then the subject of recurrent attention: the lines and limits of 'England', 'Englishness', and of the Empire (with the latter often conflated with the former). From these Gardens of England, and surrounded by the flora of 'home', the fallen anglicized the soil of foreign fields (just as Rupert Brooke had famously imagined) and, at the same time, they were themselves assertively claimed for the flag. For those conscripted to the colours both from British counties and Imperial colonies, burial in Commission cemeteries thus completed the very process of political appropriation upon which the Nation and Empire had long depended; their bodies now belonged to the Emperor-King in perpetuity. Moreover, in

\footnotetext{
${ }^{18}$ For the post-1918 'back to the land movement', see D. Matless, Landscape and Englishness, (London: Reaktion Books, 2016). See also C. Dakers, Forever England: The Countryside at War, 1914-1918 (London: I.B. Tauris, 2016), pp. 183-210, Fussell, The Great War and Modern Memory, esp. pp. 231-269, J. LewisStemple, Where Poppies Blow: The British Soldier, Nature and the Great War (London: Widenfield and Nicolson, 2016), pp. 1-26.

${ }^{19}$ For the thought and opinion of some of the pre and post-war ruralists, see A, Howkins, 'The Discovery of Rural England', in R. Colls and P. Dodd (eds.) Englishness: Politics and Culture 1880-1920 (London: Croom Helm, 1986), pp. 62-88.

${ }^{20}$ Morris, 'Gardens "For Ever England”, p. 422.

${ }^{21} \mathrm{See}$ https://www.cwgc.org/find/find-cemeteries-and-memorials/53300/tyne-cot-cemetery/design Accessed: 26 January 2018. For the importance of the 'garden' and 'country churchyard' ideal to the post-1918 activities of the IWGC, see also Dakers, Forever England, pp. 185-187.
} 
making this bodily claim, the IWGC's cemeteries also contributed to the various other post1918 territorial acquisitions which ensured that the British Empire in fact expanded in the 1920s, reaching its zenith in 1939. By then, the 'Old Contemptibles' might have long since demobilised, and the British Army might have withdrawn from its watch on the Rhine, but in the cemeteries of the IWGC an Army of the Dead stood sentinel, their cemeteries the enclaves of an Empire, their stonework the redoubts buttressing a continued commitment to colonies and the continent. ${ }^{22}$

\section{Enclaves of Empire: Reconstruction and Remembrance, 1940 -}

The outbreak of war in Europe in September 1939 obviously placed the IWGC's cemeteries at risk, although for a while the commitment of a new British Expeditionary Force to the continent did guarantee the Fallen a degree of (brief) protection. Indeed, a meeting of the Commission held in January 1940 and Chaired by Fabian Ware noted that several of these cemeteries had recently seen an influx of reinforcements. As a report tabled at a meeting of the Commission in early 1940 remarked, the 'cemeteries in France had been visited by large numbers of officers and men of the Forces', many of whom 'were visiting the graves of fathers of brothers'. ${ }^{23}$ The Commission was particularly pleased to learn that the Armistice anniversary of November 1939 was well-observed in France and Belgium, with attendance at many ceremonies bolstered by the recently arrived British Expeditionary Force (BEF). ${ }^{24}$

Nonetheless, as 'phoney war' gave way to the German blitzkrieg assault, the threat to the Commission's cemeteries - many of which lay directly in the path of the German advance - became acute. A report in December 1939, for example, noted that the 'shelters, toolhouses and other buildings in cemeteries near Festubert and Loos provided useful protection from shrapnel and shell splinters during combats overhead', whilst at Villers-Bretonneux Military Cemetery it was later discovered that attacking German forces had dug trenches close to the surrounding wall, causing (accidental) damage to some headstones. ${ }^{25}$ At Ypres, meanwhile, where the city walls still bore the scars of the fighting of 1917, French sappers blew the causeway by the Commission's massive Menin Gate memorial to the missing, an ultimately futile attempt to stem the German advance which left its mark on the nearby monument. ${ }^{26}$ Perhaps the most damage of all, however, occurred during the fighting which raged in and around Dunkirk in May $1940 .{ }^{27}$ Of course, the threat to the cemeteries also meant a threat to the Commission's staff, especially those who were British nationals. In places, and in a manner suggestive of the Commission's quasi-military nature and membership (with many staff being ex-servicemen), orders were issued telling staff in France to 'stand fast'. ${ }^{28}$ But it seems such

\footnotetext{
${ }^{22}$ For an evocative rendering of the Commission's cemeteries aimed at the British public see, S.C. Hurst, The Silent Cities: An Illustrated Guide to the War Cemeteries and Memorials to the Missing in France and Flanders, 1914-1918 (London: Times Publishing, 1929).

${ }^{23}$ The Minutes of the IWGC Committee Meetings have been catalogued and digitised, and all are now available online here:

http://archive.cwgc.org/TreeBrowse.aspx? src=CalmView.Catalog\&field=RefNo\&key=CWGC $\% 2 \mathrm{f} 2 \% 2 \mathrm{f} 2 \% 2 \mathrm{fl}$ All subsequent references to meetings are from this resource. For the reference to visits made by serving British soldiers to Commission cemeteries, see Meeting 233, 31 January 1940, p. 2. See also Longworth, Unending Vigil, p. 162.

${ }^{24}$ Meeting 232, 12 December 1939, p. 2.

${ }^{25}$ Meeting 245, 18 November 1942, p. 5.

${ }^{26}$ Longworth, Unending Vigil, p. 164.

${ }^{27}$ Meeting 249, 19 May 1943, p. 4.

${ }^{28}$ Longworth, Unending Vigil, p. 166.
} 
instructions were 'largely ignored', and staff sensibly took to the road seeking evacuation to England. ${ }^{29}$

Given such damage - actual and potential - questions of maintenance and repair were at the forefront of Commission planning as war broke in Europe. In fact, already by the spring of 1940 the Commission had sought out guarantees regarding the 6,000 British war graves in Germany, and Ware was relieved to learn via the Charge D'Affairs of the neutral United States that the German government had instructed their civil authorities to look after the IWGC's cemeteries. ${ }^{30}$ Even well into 1941 the German War Graves service appears to have remained 'favourable to the continued care of British cemeteries and memorials', ${ }^{31}$ and at the war's end the Commission in fact discovered that in Europe there 'was no doubt that the enemy had given instructions that the British cemeteries should be looked after'. ${ }^{32}$ In 1940, however, the situation was far less clear, and so as the Commission sought guarantees from the German government it also established plans to ensure the continued upkeep of those cemeteries in enemy territory. ${ }^{33}$ In Italy, for example, the Commission had long employed an anglophilic Italian aristocrat - Count Memmo - in the role of area Superintendent, and with access to maintenance funds provided via the American Embassy in Rome, Memmo pledged to continue in this role. In Greece, meanwhile, many of the Commission's staff, including numerous gardeners and the area Superintendent, were Russian and so able to stay in post even as their British colleagues had to depart for fear of imprisonment following the German invasion. ${ }^{34}$ In Belgium, in contrast, where the Commission's British staff were interned following the fall of Dunkirk (as was also the case for those staff in France) local Belgian authorities established an organisation titled 'Nos Tombes'. With IWGC approval, it supervised British and American war graves from the 1914-18 war for the duration of the German occupation. ${ }^{35}$

Such initiatives certainly went some way to alleviating Commission concerns. Yet by 1942, as Britain's war effort lurched from defeat to disaster, and as the Empire crumbled before Axis assault, the state of the Commission's war cemeteries assumed even greater importance. After all, they were 'enclaves' of Empire: that is, lingering markers of the Imperial presence, powerful symbols of a previous blood commitment to the countries, colonies and continents in which they were established, and a promissory note in stone offering reassurance (or, at least, a reminder) that at some point British Imperial authority would return. In Belgium, for example, a nation whose origins and existence were explicitly connected to key tenants of British foreign policy, and whose government sat in exile in London, the Commission specifically identified maintaining the war graves of $1914-18$ as a matter of 'prestige' as much as a practicality. ${ }^{36}$ In Africa, too, where the Imperial presence and power was strained by the demands of the war, a combination of local authorities and Commission appointed staff were tasked with maintaining the cemeteries. In 1942, the Commission was pleased to learn that graves in Kenya, Northern Rhodesia, Nyasaland, Tanganyika and Zanzibar were all in good order, and that the graves were 'generally neat and well looked after and are surrounded by carefully tended grass and shrubs; many planted with flowers' ${ }^{37}$

\footnotetext{
${ }^{29}$ Longworth, Unending Vigil, pp. 166-167.

${ }^{30}$ Meeting 234, 10 April 1940, p. 6.

${ }^{31}$ Meeting 238, 10 September 1941, p. 3.

32 Meeting 232, 20 December 1944, p. 5.

${ }^{33}$ Meeting 237, 22 July 1941, p. 6.

${ }^{34}$ Meeting 237, 22 July 1941, pp. 3-4.

${ }^{35}$ Meeting 244, 23 September 1941, p. 6.

${ }^{36}$ Meeting 245, 18 November 1942, p. 2.

${ }^{37}$ Meeting 244, 23 September 1942, Appendix B.
} 
Keenly aware of the vulnerability of their cemeteries to accidental battle damage (especially as Allied Armies returned to Europe in 1944), the Commission began the work of repair just as soon as an area was no longer the focus of active operations. Thus, by 1943, cemeteries in areas of the Middle East - a traditional bastion of British Imperial power - were deemed sufficiently safe to allow for the IWGC's return. ${ }^{38}$ A similar eagerness to 'return' was apparent in Europe. Less than three weeks after the Allied invasion of Normandy, for example, the Commission had already contacted the military authorities requesting permission to land a team, and by $5^{\text {th }}$ October 'the first three Commission officers to return to France raced each other off the boat at Arromanches' ${ }^{39}$ By the year's end the Commission was also on the ground in Belgium, where it's officers were pleased to discover that the damage to the post-1918 cemeteries was relatively minor. Indeed, when British troops liberated Belgium at the end of 1944 they discovered that communities local to the IWGC's cemeteries had adopted the memorials and markers, with an officer of the Commission noting that this 'was typical of the reverent care of British graves taken by local people in France and Belgium during the enemy occupation'. ${ }^{40}$ Similarly reassuring reports emerged from France towards the end of 1944, where it was discovered that whilst there was some battle damage and general neglect to make right, on the whole 'the cemeteries were in a much better condition than the Commission had hoped or expected at one time'. ${ }^{41}$ Crucially, there was very little evidence of 'deliberate destruction'. ${ }^{42}$

If, by 1944, the IWGC was keen to return to Europe to undertake the work of repair and reconstruction, it was equally keen to build anew. Indeed, once landed in Normandy, for example, an IWGC team quickly requested from the military authorities suitable facilities so that they might operate 'in a military area' and thereby take any necessary 'immediate steps' to improve the condition of the temporary battlefield cemeteries established in the days after D-Day. ${ }^{43}$ Likewise, a few months later, as the fighting still raged in Europe, the Commission's officers were on the ground in the Middle East, securing land and negotiating agreements in a manner not entirely dissimilar to that conducted by many previous generations of Imperial agents. ${ }^{44}$ In Gibraltar, key to Britain's one time dominance of the Mediterranean and gateway to the Empire of the East, the Commission went so far as to commission a new, more robust Cross of Sacrifice, which was to be positioned 'high up on the Rock' where it would 'be seen from the sea' ${ }^{45}$ Such planning made clear that as Allied victory loomed the Commission was absolutely committed to reclaiming lost territory, rebuilding old outposts, and reasserting the visibility of their presence via new memorials and monuments. Much like Prime Minister Winston Churchill's broader plans for Imperial restitution and reconstruction, therefore, the IWGC was similarly committed to a form of architectural and horticultural recolonization. Consequently, as British Armies fought their way back through Europe, North Africa, the Middle East and Burma the Commission's agents and officers followed close behind, repairing, reconstructing, surveying, burying, and in due course once again embarking upon activities intended to appropriate and anglicize (or re-anglicize) 'corners' of foreign fields.

\footnotetext{
${ }^{38}$ Meeting 248, 26 March 1943, p. 2.

${ }^{39}$ Longworth, Unending Vigil, p. 185.

${ }^{40}$ Meeting 262, 18 October 1944, p. 3.

${ }^{41}$ Meeting 262, 18 October 1944, p. 7.

${ }^{42}$ Meeting 232, 20 December 1944, p. 5.

${ }^{43}$ Meeting 260, 21 June 1944, p. 8.

${ }^{44}$ Meeting 266, 21 February, pp. 5-6.

${ }^{45}$ Meeting 267, 21 March 1945, p. 6.
} 
This latter objective also returned to the fore of contemporary debate, both within and beyond the IWGC, a key issue in need of renewed resolution: what to do with those killed and missing. During the First War, we recall, Imperial authorities had decreed that the 'Glorious Dead', without exception for rank or status, were buried close to where they fell, and this was a precedent that the IWGC was keen to follow (albeit it subject to renewed discussion). After all, how could foreign fields be made 'English' if there was no corporeal 'seed' to plant? ${ }^{46}$ How could the Empire be reconstituted without making explicit the blood sacrifice the victory had demanded? Fortunately for the Commission's relief, the question of what to do with the bodily remains of the fallen did not in the end produce the same intensity of debate as had been the case after 1918, and the issue of overseas burial versus repatriation was actually agreed in quick order. Indeed, within a month of victory over Japan the matter had been resolved, and with the agreement of all 'participating governments' the IWGC was ready to publicly announce that 'the repatriation of bodies of members of his Majesty's Forces buried overseas shall not be undertaken or allowed'. ${ }^{47}$ 'Public reaction' to the decision was, says the IWGC' official historian, Philip Longworth, 'hardly noticeable'. ${ }^{48}$

The power of precedence - and especially the example provide by the Great War similarly informed the Commission's discussions regarding the precise manner in which the dead of the new conflict were to be commemorated. In part, this was also due to the fact that the personalities at the helm remained a constant. For instance, Sir Fabian Ware, the Commission's founder, remained in the role of Vice-Chair until his retirement in 1948. Even where retirement of death prevented the continued service of previous Commission stalwarts - such as the Head of Kew Gardens - successors of similarly standing, status and outlook were quickly found to ensure continuity. For instance, the architect given responsibility for overall co-ordination of the Commission's post-1945 activities was Hubert Worthington, a long-time associate of Lutyens, whilst Philip Hepworth, a key figure in the Royal Academy, took charge specifically in France. In Italy, meanwhile, the Commission's commitment to the ideal of an 'English Garden' was in very safe hands - the architect in charge here was Louis de Soissons, well known for his work at Welyyn Garden City'. ${ }^{49}$ Such continuities of staff and continuities of policy understandably led to continuities in commemorative vision and aesthetic. As early as 1940, for instance, the moment when the IWGC had first secured government approval to begin its 'new work', Ware and staff had already decided that 'the pattern of headstone used in the war 1914-1921 be also adopted for the present war'. ${ }^{50}$ This was decision was warmly received by Lutyens, who had firmly argued that the Commission should 'keep the same headstones, the same monuments' as in a 'hundred years time 1914 and 1939 will be part of one war'. 51 Such thinking and such decisions duly paved the way for other, similar, commemorative repetitions. Indeed, already by 1940 some of those killed in the 'present war' had been buried in the cemeteries originally established in the 1920s, an act which explicitly fused the two conflicts in memory and meaning. ${ }^{52}$

The Commission's post-1945 activities were thus powerfully shaped by the 'same general architectural and horticultural treatment' as the 'last war', a 'treatment' which had first

\footnotetext{
${ }^{46}$ Meeting 261, 16 August 1944, pp. 4-5.

${ }^{47}$ Meeting 273, 27 September 1945, p. 2.

${ }^{48}$ Longworth, Unending Vigil, p. 182.

${ }^{49}$ Longworth, Unending Vigil, pp. 179-180.

${ }^{50}$ Meeting 234, 10 April 1940, p. 6.

${ }^{51}$ Longworth, Unending Vigil, p. 163.

${ }^{52}$ Longworth, Unending Vigil, p. 162.
} 
been sketched out by the likes of Ware, Lutyens, and Blomfield back in the $1920 \mathrm{~s} .{ }^{53}$ In places, the ground - in both cultural and environmental terms - was noticeably hospitable to this new round of precedent-inspired commemorative construction. For if the architectural and horticultural style used by the Commission in the 1920s 'worked' in northern France and Flanders, a region with a similar climate to England and a region with which there was also a deep rooted historical connection, the same was true of the geography which received the Allied invasion in June 1944. In terms of Royal rule, Normandy had even at one point been 'one' with England, a fact recorded in the genealogy of the British monarchy and aristocracy. None other than Field Marshal Montgomery, Commander of the Allied Land Forces, was Norman French in ancestry, something of which he was very proud and which later led to one Norman community taking his name in gratitude for their liberation. Such ancestral and historical connections visibly informed the IWGC cemetery constructed on the outskirts of Bayeux, the town which already possessed a well-known document commemorating an earlier cross-Channel invasion (the Bayeux Tapestry). Thus, the memorial accompanying the cemetery - unveiled in 1955 - features an inscription, in Latin, declaring 'We who were Conquered by William have liberated the fatherland of the Conqueror'. ${ }^{54}$ Elsewhere, the cemetery includes the other now familiar marks of the Commission's medievalism, most notably the Cross of Sacrifice, with the inlaid Crusader's sword now also finding new meaning given the rhetorical basis upon which the overall commander of the invasion, General Eisenhower, had established the operation: as a 'Crusade' of liberation.

In other locations, however, the favoured styles of the IWGC - English medievalism, Gothic revival, neo-classicism, and especially the English Garden or Country Churchyard were far less suitable. In the Far East and North Africa, for instance, realising the usual 'English Garden' was certainly made difficult (and occasionally impossible) by the local climate. ${ }^{55}$ At Alamein, the architect in charge specifically designed structures to 'keep out drifting sands' as well as 'shady pagodas and cool terraces to provide shelter from the sun' ${ }^{56}$ Elsewhere, cacti replaced 'thirsty roses', whilst growing a lawn proved a particular problem. ${ }^{57}$ Of course, the Commission was no stranger to such challenges, and some of those cemeteries built in the 1920s had similarly contended with the difficulties posed to an English garden (which demands English quantities of rain) by heat and humidity, and by dust and deserts. ${ }^{58}$ In the main, careful choice of planting and sensitivity to the local landscape (as well as to the national and cultural identities of the Fallen) provided a route through the potential impasse offered by challenging environmental conditions, the result being nationally-specific gardens which nonetheless still situated the dead in an Imperial context.

More problematic however, and less receptive to horticultural subtlety, was the political climate. After all, the defeats and retreats of 1940-42 had dealt British imperial power a fatal blow, whilst the alliance with Franklin D. Roosevelt's United States also committed the British

\footnotetext{
${ }^{53}$ Longworth, Unending Vigil, pp. 178-179.

${ }^{54}$ For some details about this memorial, see S. Edwards, 'The Beginning of the End: D-Day in British Memory' in M. Dolski, S. Edwards and J. Buckley (eds.), D-Day in History and Memory: The Normandy Landings in International Remembrance and Commemoration (Denton: University of North Texas Press, 2014), pp. 85-130. ${ }^{55}$ Summers, British and Commonwealth War Cemeteries, p. 46.

${ }^{56}$ Ibid.

${ }^{57}$ Ibid.

${ }^{58}$ For some details, see R. Fuchs, 'Sites of memory in the Holy Land: the design of the British war cemeteries in Mandate Palestine', Journal of Historical Geography, 30 (2004), pp. 643-664; A. Yilmaz, 'Memorialization of Broken Ground: Gallipoli War Cemeteries and Memorials Designed by Sir John James Burnet', Journal of the Society of Architectural Historians, Vol. 73, No. 3, (2014), pp. 328-346.
} 
government to a policy of imperial restructure in the interest of colonial independence and national self-determination, the much vaunted cause for which the Allies - or, rather, the 'United Nations' - had fought. As a result, the two decades immediately following 1945 saw the Union Jack come down in various locations across the globe: India, Pakistan, Sri Lanka, Palestine, Suez, Malaya, Cyprus, Jamaica, Trinidad. ${ }^{59}$ Yet, at the same time, this was also the very era in which, via other means, the British Imperial state - via the IWGC - nonetheless marked its continued quasi-existence (and recent sacrifices) via architectural and horticultural forms which were, in effect, echoes of a now long gone Edwardian Golden Age. The 'new' cemeteries of the IWGC, resplendent in their clean lines, Portland stone, manicured lawns, wild flowers, and Kipling epitaphs, and established from Bombay to Baghdad, and from Ranville to Rangoon, thus belied the extent to which the Empire for which those interred had sacrificed was in fact just then disappearing. To be sure, such dissonance between memorial and moment, politics and place, again had precedent. Medieval crusader iconography had certainly 'jarred' when considered for use by the IWGC in the cemeteries established after 1918 in the Middle East (and especially the Holy Land). ${ }^{60}$ In 1941, rioters in Iraq even vandalised several of the Commission's cemeteries, ${ }^{61}$ with the Cross of Sacrifice at the Baghdad Cemetery specifically singled out for destruction. ${ }^{62}$ By the 1950 s, however, when many of the Commission's post1945 cemeteries were completed, the dissonance between idea and era was perhaps even more profound. For as the Commission's new Imperial architecture was built, the Empire itself fell. Combined with the sheer scale of the Commission's post-1945 activities - which involved, in total, 24,000 sites, and most outside of Europe - this fact ensured that the IWGC was at work in locations where 'the adjective "Imperial" would soon become a pejorative word'. ${ }^{63}$

The post-1945 cemeteries were thus an anachronism carved into stone. Inspired by an Edwardian aesthetic which was itself already rather nostalgic when first deployed in the 1920s, these cemeteries suggested the eternal even as the Empire they commemorated collapsed. Seen in these terms, the post-1945 cemetery building programme of the IWGC was amongst the very last instances of concerted and combined Imperial endeavour; the architecture of the Empire's twilight. By the 1960s, newly independent colonies would fight their own battles, and bury their own dead, and even the 'white dominions' asserted a far greater degree of autonomy in foreign policy, a point especially apparent in the divergence between the UK and Australia regarding the war in Vietnam. The former always refused American pleas for even a token contribution, whilst the latter steadfastly committed its forces to the region where they fought and died with their American allies. They were later repatriated to their homeland, and buried by Australian authorities, in Australian military cemeteries. ${ }^{64}$ The British government would itself do similar following the withdrawal from Suez, the 1956 Anglo-French debacle which

\footnotetext{
${ }^{59}$ For the wartime and post-war Anglo-American relationship and some of the tensions in the RooseveltChurchill connection over aims and objectives, see C.J. Bartlett, The Special Relationship; A Political History (London: Longman, 1992); W.R. Louis and H. Bull, The Special Relationship: Anglo-American Relations Since 1945 (Oxford: Oxford University Press, 1986). For details about the end of the British Empire, see P. Clark, The Last Thousand Days of the British Empire (New York: Bloomsbury, 2010).

${ }^{60}$ For details about the Commission's cemeteries in the Holy Land, see Fuchs, 'Sites of memory in the Holy Land: the design of the British war cemeteries in Mandate Palestine', pp. 643-664.

${ }^{61}$ Longworth, Unending Vigil, pp. 178-179.

${ }^{62}$ Meeting 238, 10 September 1941, p. 3.

${ }^{63}$ Longworth, Unending Vigil, p. 187.

${ }^{64} \mathrm{See}$ https://www.dva.gov.au/commemorations-memorials-and-war-graves/remembering-our-war-dead/ourvietnam-war-dead Accessed: 26 January 2018.
} 
confirmed that this was indeed the age of Imperial retreat. ${ }^{65}$ The bodies of the 16 British servicemen killed during the Crisis were brought home, even despite the fact that the Commission had a cemetery containing both First and Second World War burials nearby. Such a decision was understandable, for like British power more broadly this cemetery had been battered and broken during the Crisis, with an Egyptian crowd 1,000 strong smashing the gates and threatening the staff. ${ }^{66}$ By 1963 , such precedents, together with a changed global political landscape and the scaling back of overseas commitments, ensured that repatriation was now the norm for those killed whilst on active duty overseas ${ }^{67}$ Since 2003, repatriation has become official policy, with those killed in the recent wars in Afghanistan and Iraq returned to Britain in sombre ceremonies at locations like Royal Woottan-Bassett. ${ }^{68}$

Imperial retrenchment, colonial independence, and military withdrawal from 'East of Suez' thus ensured that in the post-1945 age of austerity, depression and decline not even the Dead could now be spared to man the Frontier. Not unlike the monuments left by the Roman garrison's which had once guarded the windswept heights of Hadrian's Wall, but whose legions were later recalled to the metropole by a fading imperial authority, the cemeteries built by the IWGC after 1945 now marked the borders of an Empire that, in the conventional terms of 'Hard Power', had gone. This was a fact which the 1960 change in name - from 'Imperial' to 'Commonwealth' War Graves Commission (CWGC) - explicit acknowledged, and also a fact suggested by some of the Commission's subsequent activities. Indeed, amongst the Commission's main post-war roles has been the maintenance and repair of those cemeteries 'out there' on the periphery of the once mighty Empire, and now threatened by regional conflict, disorder and disruption. The civil war in the Lebanon, for example, saw the Commission's two cemeteries at Beirut suffer significant damage, with the 1939-45 cemetery 'hit by bombs and gunfire' causing damage to 873 headstones, and the total destruction of the Cross of Sacrifice. ${ }^{69}$ Elsewhere, construction plans in Libya saw the Commission's Bengahzi cemetery threatened with demolishment in $1982,{ }^{70}$ whilst at times the Commission's memorials were the specific target of those who saw in them the highly political architecture of a now departed but still very much disliked Empire. War graves in the Republic of Ireland, for example, were often vandalised, particularly during the tensions of The Troubles. ${ }^{71}$ Even more recently, western intervention and subsequent civil war in Iraq has similarly resulted in damage to the Commission's cemeteries and memorials, with The Times reporting in April 2016 that following the departure from the region of the British military, Commonwealth war graves had been 'left to crumble in the dust'. ${ }^{72}$ Like the forts and stonework of other once mighty Empires, Britain's war cemeteries, dispersed across the globe, are now vulnerable to changes in climate, both political and meteorological.

\footnotetext{
${ }^{65}$ For details of the crisis and its impact on Britain's international standing, see W.S. Lucas, Divided We Stand: Britain, the US and the Suez Crisis (London: Hodder and Stoughton, 1991).

${ }^{66}$ Longworth, Unending Vigil, p. 216. See also Meeting 398, 20 December 1956, p. 6.

${ }^{67}$ J. Summers, British and Commonwealth War Cemeteries (Oxford: Shire Publications, 2010), p. 51.

${ }^{68}$ Ibid. See also 'Wootten Basset marks the end of reparations', BBC News, 31 August 2011: http://www.bbc.co.uk/news/uk-england-wiltshire-14726697 Accessed: 26 January 2018.

${ }^{69}$ Meeting 551, 16 December 1982, p. 6. Damage was later repaired by the Commission - see Meeting 554, 22 September 1983, pp. 4-5.

70 Ibid.

${ }^{71}$ See Meeting 554, 22 September 1983, p. 5.

72 The Times, 25 April 2016: https://www.thetimes.co.uk/article/britains-war-graves-left-dusty-and-dishonoured8x3czvj9s Accessed: 26 January 2018. See also The Telegraph, 10 November 2013: http://www.telegraph.co.uk/history/britain-at-war/10438147/Iraq-cemetery-containing-graves-of-Britishservicemen-is-destroyed.html Accessed: 26 January 2018.
} 


\section{The Last Post: The Falklands War and San Carlos Cemetery}

Tellingly, the first and last occasion since 1945 in which the CWGC has been tasked by the British government with constructing an overseas military burial ground powerfully revealed the role of its cemeteries as architectural outposts of a now largely disappeared Empire. The event at the centre of this new commemorative endeavour was the 1982 Falklands War between the United Kingdom and Argentina, a quasi-imperial confrontation precipitated by the Argentinian invasion and occupation of the islands claimed by the military junta in Buenos Aires as sovereign territory, and named 'Los Malvinas'. The successful British campaign to reclaim the Islands was brief, lasting just over two months, between April and June 1982. Even so, the price in blood was not insignificant: 255 British servicemen were killed, together with 649 Argentinians. $^{73}$

In light of such losses, the construction of a new military cemetery was surely to be expected, and so too therefore was the leading role to be played by the CWGC, experts in the field and an understandable authority to which the British government naturally turned once hostilities had ceased. But the synergy between the conflict and the Commission was also linked to the terms upon which the British government had gone to war, and the terms upon which military intervention was justified to press and public at both home and abroad. For, aided and abetted by the tabloid press, Thatcher's administration purposefully invoked memories of the Second World War in order to rationalise the military operation, and thereby impart to it a clear meaning. Such 'keying' between past and present began soon after the Argentinian invasion, which was framed in the British press with reference to an oftcontemplated but never realised counter-factual narrative which imagined a successful German invasion of Britain. The fact that the invading power - Argentina - had long been suspected of harbouring Nazi war criminals, and that the military junta that ordered the attack was in many respects 'fascist', only added to the traction of a 1940s era narrative construction. ${ }^{74}$

If, for many Britons, the Argentinian invasion of the Falklands called to mind the long imagined terror of the Nazi jackboot in an English village, it did not require much effort subsequently to invoke other iconography and ideas of the 1940s and of Britain's 'Finest Hour'. In the press, the departure of the Task Force from Portsmouth called to mind the much vaunted 'Dunkirk Spirit', and an armada of 'little ships' did indeed accompany the Navy's aircraft carriers and destroyers out of the harbour. Later, the courage of Royal Navy Harrier pilots taking to the sky against a numerically superior enemy was equated with the heroism of 'the few' who valiantly fought over the White Cliffs of Dover in 1940, whilst the victory of British paratroopers at Goose Green was, as Mark Connelly suggests, the new Dunkirk and Battle of Britain rolled into one'. ${ }^{75}$ Such past-present connections understandably ensured that the actual British landings in the Falklands - which took place just a couple of weeks before the $38^{\text {th }}$

\footnotetext{
${ }^{73}$ For a history of the Falklands conflict, see M. Middlebrook, The Falklands War (Barnsley: Pen and Sword, 2012).

${ }^{74}$ Significantly, the war occurred just as the counter-factual of a Nazi invasion of Britain was receiving new attention, and also at the very same moment as several popular histories of the German occupation of the Channel Islands drew public attention to the events and details of the only piece of British territory occupied in the 1940s. See, for instance, the success of The Eagle has Landed (1976) and Len Deighton's SS-GB (1978). 75 See M. Connelly, We Can Take It! Britain and the Memory of the Second World War (London: Pearson, 2004), pp. 271-273. See also L. Noakes, War and the British: Gender, Memory and National Identity (London: I.B. Tauris, 1998), pp. 103-133. For a brief discussion of the connections between the Falklands War and the Second World War in terms of commemoration, see K. Burnell and R. Jones, 'Public/Private Commemoration of the Falklands War: Mutually Exclusive or Joint Endeavours', in M. Andrews (ed.) Lest We Forget: Remembrance and Commemoration (Stroud: The History Press, 2011), pp. 46-49.
} 
anniversary of the Normandy assault - were reported with frequent and specific reference to D-Day. On BBC television, for example, journalist Robert Fox even declared that at San Carlos Bay the British landing craft had gone in 'exactly according to the D-Day model'. ${ }^{76}$ Even the landscape of the Falklands played its part in this very British narrative, with the Islands' rocky peaks and windswept moors leading more than one British servicemen to assume that he'd been dispatched to recover an archipelago lying somewhere off the west coast of Scotland.

Such layering of history, memory and moment paved the way for a variety of postvictory activity, from VE Day inspired street parties to the more formal processes and practices of commemoration. Thus, following discussion in the media, and after a request from the Thatcher government, the CWGC soon became involved in plans to commemorate the Falklands dead. By the time of the Commission's meeting on 16 June 1982 - just two days after the Argentinian surrender - some of the key issues to be resolved had already been broached, and a plan was beginning to develop. At this stage, however, the Commission was rather reluctant to become too publicly involved in plans regarding treatment of the British war dead, fearing that they might be the subject of criticism given their long running association with overseas burial. Indeed, there was significant debate in the British press, sparked by speeches in Parliament as well as letters from members of the public, regarding the issue of repatriation, with many appearing to favour bringing the bodies home, especially after footage emerged of a relatively hasty 'mass burial' of British troops at Goose Green. ${ }^{77}$ In such a context, the CWGC's Secretary remarked during a meeting that it was 'inevitable that the Commission's position in regard to deaths during operations to repossess the Falkland Islands would not be fully understood', particularly as some unfortunate 'mis-reporting' had also muddied the water. ${ }^{78}$ The situation was made still more complicated (and sensitive) by other communications from members of the public expecting the Commission - and government to treat the dead of 1982 with reference to the policies of 1918 and 1945 . In one letter to the Commission, a correspondent drew special attention to the overseas burial of a loved one who fell in the 1939-45 war, noting that 'if repatriation were to be allowed from the Falklands, the repatriation of the remains of that soldier would be requested' ${ }^{79}$ At stake here, was precedent: should the Commission follow the example of 1918 (and of 1945), and bury the dead where they fell. Or should they offer repatriation (in line with general procedure since the early 1960s) but risk establishing this as precedent, and thereby find themselves inundated with requests for the return of long buried bodies from previous conflicts.

To be sure, this latter eventuality was never that likely, but the letter - and its discussion at a meeting of the Commission - makes clear the challenging ground the Commission now had to navigate. By the next meeting, in September 1982, this issue had been resolved, and the government had indeed chosen to follow the policy established in 1967: next of kin were given the choice of repatriation or burial in the Falklands, and, understandably given the distances involved, most chose repatriation. The Commission therefore knew by this point that they would likely be establishing a cemetery for 'between ten and twenty' burials, and in turn this prompted discussion over a suitable location. The Commission already maintained 33 war graves in Port Stanley Cemetery (from the First and Second World Wars), and the 1982 dead might have been interred here. But there was 'a strong feeling from the military command in

\footnotetext{
${ }^{76}$ Connelly, We Can Take It!, p. 273.

${ }^{77}$ Meeting 549, 16 June 1982, p. 12.

${ }^{78}$ Meeting 549, 16 June 1982, p. 12.

${ }^{79}$ Meeting 549, 16 June 1982, p. 12.
} 
the Falklands Islands that the reburials should be in the general area of Ajax Bay and San Carlos Water where a considerable number of causalities had already been temporarily buried' ${ }^{80}$ Such a location was in line with the Commission's established policy of burial at or close to the field of battle, whilst some on the Board also believed the existing Port Stanley Cemetery lacked the necessary aesthetic qualities, arguing that it would be 'far better if it [the cemetery] was sited in a completely new area such as San Carlos'. ${ }^{81}$

With San Carlos Water thus identified as the area most suitable for a new cemetery, the Commission dispatched its officers to survey the site and identify a specific location. This had to be done in quick order, as public and political pressure demanded that the cemetery and memorial be in place before the next Falklands winter (June-August), which set a completion deadline of April 1983. ${ }^{82}$ In due course, a site overlooking the water was identified, with the Commission's man on the ground recording that it was particularly attractive. With the support of the local military commander and the MoD, troops were employed to prepare the ground and transferring the burials, whilst the Commission began the necessary commemorative work. Particular attention was paid to the overall design aesthetic, and to the landscaping. Indeed, the latter was deemed so important that one member of the Commission was concerned that next of kin visiting for the dedication might be disappointed. For whilst the 'Commission would do its best to maintain the cemetery to its normal standards, because of the climate the horticulture would never look as good as that in northern Europe'. The Commission's President, however, suggested that 'he could not imagine that the next-of-kin would expect to find a cemetery in the Falklands laid out like English garden' ${ }^{83}$

But of course he was wrong; that is exactly what the families of the fallen expected, exactly what the Falkland Islanders expected, and exactly what British press and politicians similarly expected. For the Commission's almost sixty years of work had firmly established and consolidated a particular ideal for the military cemetery, an ideal specifically arranged around the concept of an English garden. Such garden cemeteries, built in their hundreds after the two world wars, had claimed the dead for England and Empire, and then put them to work on that Empire's behalf. In their regimented ranks and before the iconography of the Edwardian State, their bodies, surrounded by rose, and hawthorn, and poplar and yew, made foreign corners home, and foreign soil 'English' (their multi-ethnic and multi-cultural conscripts notwithstanding). It might now have been 1982 rather than 1918, but this idea was nonetheless deeply rooted in the institutional memory and purpose of the CWGC, and in the cemetery established overlooking San Carlos Bay it had one final flourish. An unexpected Imperial war, and an unexpected Imperial victory, bequeathed a final space in which the Commission could practice its carefully controlled form of Imperial memory-making.

The cemetery at San Carlos was dedicated - on time and on schedule - in $1983 .{ }^{84}$ The fourteen headstones are of the familiar CWGC style, complete with carefully engraved military insignia. As precedent dictates, they are arranged in flower beds, which bloom brightly in the South Atlantic's spring and summer. The lawn - long an obsession within the CWGC, and

\footnotetext{
${ }^{80}$ Meeting 550, 16 September 1982, p. 10.

${ }^{81}$ Meeting 550, 16 September 1982, p. 10.

${ }^{82}$ Meeting 550, 16 September 1982, p. 10.

${ }^{83}$ Meeting 550, 16 September 1982, p. 11.

${ }^{84}$ As the details recounted here make clear, the San Carlos Cemetery - sometimes referred to as Blue Beach Cemetery - was designed and built by the Commission on behalf of the Ministry of Defence, and so it's status within the Commission is a little different to those cemeteries established after the First and Second World Wars.
} 
something which the Commission was just then discussing due to changing horticultural practices at its European cemeteries - is manicured. Not unlike Tyne Cot, the cemetery is surrounded by a boundary wall - albeit of local stone (rather than Portland) - which gains height towards the back in order to allow space for commemorative tablets listing the names of the British dead. This wall, designed to recall the sort of structures long used in the islands to coral sheep, is squat, strong, stout. Save for the headstones, it has the look of a fort, for such it is. Indeed, in its own way, it is as important to the maintenance of British sovereignty as the other MoD building project of the post-1982 period, the vast military complex of airfield and barracks erected at Mount Pleasant. At the latter, the soldiers and airmen of today beat the bounds of Imperial possession; at the former, the soldiers of yesterday, their bodies buried in an English garden, make a territorial claim as old as history. Blood was the coin of the purchase they made, their monuments a record of ownership, their cemetery a garrisoned fort, the last outpost of an Edwardian Empire of the Dead.

\section{Conclusions: An Informal Empire of Memory}

The idea that monuments to conflict encode and express forms of political memory is now well-established. John Mayo has argued that war memorials are forms of 'political landscape', whilst Jon Davies has similarly suggested that twentieth century war memorials are the 'boundary markers' of the West, playing a powerful role in the construction of political and social identities, delineating 'us' from 'them'. ${ }^{85}$ Elsewhere, Ron Robin has convincingly shown how the war cemeteries built by the American Battle Monuments Commission (ABMC) after 1918 and again after 1945 were attempts by an emerging Imperial power - the United States to assert its arrival via assertive and nationally distinctive aesthetic forms. These were architectural demonstrations of power, presence and politics erected on those landscapes upon which American soldiers had fought and bled. ${ }^{86}$ Yet amidst all this work interrogating the role of war memory in identity construction, territorial delineation, and political appropriation, surprisingly little attention has been paid to the carefully contrived Imperial pretensions of the post-1945 Imperial War Graves Commission, the very era in which the Empire fell. Indeed, outside of the official histories by Philip Longworth, T.A. Gibson and G. Kingsley Ward, the IWGC's post-Second World War activities have largely been overlooked or dismissed as mere architectural afterthoughts, repetitions of forms and styles originally practiced and perfected in the 1920 s. ${ }^{87}$ Similar lack is apparent with regard to the only occasion subsequent to 1945 when the Commission - tellingly renamed the Commonwealth War Graves Commission - initiated the construction of a new cemetery and memorial, in the Falklands.

In part, such neglect makes sense: the commemorative forms used in the 1940s-50s, and again in 1982-83, did indeed follow precedent, and in this sense they can certainly be understood as, in effect, repetitions on a theme. But herein lies their unappreciated significance. For the specifically 'Imperial' commemorative aesthetic of the 1920s had traction; the Empire had just sacrificed nearly a million soldiers, and in the war's aftermath that Empire would grow,

\footnotetext{
${ }^{85}$ See J. Mayo, War Memorials as Political Landscape: The American Experience and Beyond (New York: Praeger, 1988); J. Davies, 'Reconstructing Enmities; War and War Memorials, The Boundary Markers of the West', History of European Ideas, Vol. 19, No. 1-3, (1994), pp. 47-52.

${ }^{86}$ R. Robin, Enclaves of America: The Rhetoric of American Political Architecture Abroad, 1900-1965 (Princeton: Princeton University Press, 1992).

${ }^{87}$ Longworth, Unending Vigil; Gibson and Ward, Courage Remembered. A notable exception is the excellent article by H. Muzaini and B. Yeoh, 'Memory-making "from below": rescaling remembrance at the Kranji War Memorial and Cemetery, Singapore', Environment and Planning, Vol. 39, (2007), pp. 1288-1305.
} 
gaining new territories and possessions. By 1942, however, that Empire was in headlong retreat, all claims to continued Imperial overlordship in Africa and Asia fatally weakened by military defeat and economic decline, and hobbled by contemporary Allied propaganda and the rise of a new behemoth, the United States. For President Roosevelt, Britain's wartime creditor and benefactor, Allied victory was to be the death knell for 'old' Empires; the age of 'National Self-Determination' had arrived. This was a war for such lofty ideals as 'Freedom', 'Liberty', 'Democracy'; no place here for the condescension of Imperial patriarchy. Despite such language, and despite the political and economic realities of the post-1945 period, when it came to the work of mourning and memorialising British and 'Commonwealth' governments (as they were now known) nonetheless committed themselves to the resurrection of inescapably 'Imperial' aesthetics. Even as the Empire fell, this commitment remained. The result is an architectural irony and a landscape at odds with the moment that made it: the post-1945 cemeteries of the IWGC expanded the now defunct Empire's commemorative possessions just as the actual deeds to land were surrendered. The cemeteries of the IWGC thus record, in stone, statuary and shrubbery, the moment of Imperial departure; or, rather, the moment of formal imperial departure. For in a sense, establishing this Empire of Memory was part and parcel of a wider post-war attempt to cultivate continuing ties of sentiment and 'soft-power' so as to ensure the new 'Commonwealth' might weather the storms of independence and decolonisation. Indeed, a map c.1956 detailing the IWGC's many commemorative outposts would look not unlike some of those now famous cartographic expressions of British influence popular in the late nineteenth century, albeit with those colonies, possessions and military bases once 'coloured pink' replaced by military cemeteries, monuments and memorials.

The one exception to this story of contemporaneous political withdrawal and commemorative appropriation nonetheless proves the broader point. For in the aftermath of the bloody imperial war fought in the South Atlantic in 1982 the Commission, at the behest of the British government, built its first and last post-1945 overseas war cemetery. Given the slumbering imperial sentiments the conflict had roused, the decision to follow precedent in the design of this cemetery surely made sense. British blood had been spilt to keep the islands British (just as the people of the Islands, deploying the language of self-determination, had demanded). Indeed, in certain respects, the operation had itself been an Imperial enterprise, involving Gurkha troops recruited in Nepal, Chinese labourers (in the Merchant Navy), and even requests to certain Dominion allies (Australia and New Zealand) to relieve the Royal Navy of Cold War responsibilities so that it might assemble a fleet to sail to the South Atlantic. Seen in this context, invoking the well-established theme of an English Garden was itself an act of symbolic repossession, a claim of ownership which ensured that the wind-swept heights over San Carlos Bay were seen to be 'British'. But whereas after 1918 similar claims had demanded the continued service of all the fallen, by 1982 the State's post-mortem hold on the dead - like the very Empire itself - had long since waned. Britain was no longer the pre-eminent global power, its political and economic reach had shortened, its colonies self-governing, its Empire gone, its social democracy altered, its soldiery volunteer, not conscripted. And so after 1982, with just a few exceptions, the bodies of the British dead came home, returned to their grieving families, reclaimed as sons, and brothers, and husbands, their service to and for the State completed. The English Garden bequeathed by the conflict, seeded with grass, heather, and the bodies of fourteen British servicemen, and buffered by a stiff on-shore breeze, is thus the final flourish of an Edwardian ideal, and the last fort of a now fading Empire of Memory. 